\title{
Researches on Evaluation and Warning Index of Forest Resources Ecological Environment
}

\author{
Zhen-Cai LI ${ }^{1, a}$ \\ ${ }^{1}$ School of Business, Linyi University, Linyi, P.R.China, 276000 \\ aabclzc@sina.com
}

Keywords: Forest resources ecological environment, Evaluation and warning index.

\begin{abstract}
Forest resources have strategic significance for sustainable economic and social development. At present, China's forest ecological environment is faced with serious soil erosion, forest pest, acid rain and other problems. Using ecology and environmental sciences' basic theory, this article will establish a set of scientific evaluation and warning index of forest resources ecological environment to provide reference for formulating protection measures.
\end{abstract}

\section{Introduction}

Nowadays, self- maintaining physical environment of forest has become a kind of tempting resources to human being( Jenkins, 1997; Richard, 1997).People from all over the world have gradually realized that the forest play an important role in inhibiting environment deterioration, protecting biodiversity, coping with climate change and other aspects ; the forest's sustainable management aroused the world attention ( FAO, 2007).

However, United Nations Environment Programme pointed out that $80 \%$ of the original forest has been destroyed in the world and the forest continues disappearing gradually at the speed of 150000 square kilometer annually (UNEP, 2000).In China, with exploitable forest resource continuous attenuating, forest coverage rate is only $13.92 \%$, while the world average forest coverage rate up to $23 \%$. Accounting for only $4 \%$ of world forest area, China's existing forest area is $134000000 \mathrm{hm} 2$; and the per capita forest area is $0.12 \mathrm{hm} 2$ only equivalent to $12 \%$ of the world average per capita forest area. Moreover, the forest is faced with serious soil erosion, forest pest, acid rain and other problems. Therefore, we can say that the situation of China forest resources ecological environment situation is serious, and there is the trend of further deterioration. Accordingly, forest ecological environment monitoring has become a key problem for the sustainable development of china. This article will establish a set of scientific evaluation and early warning index system of forest resources ecological environment to provide basis for monitoring and developing protective measures for forest ecological environment.

Forest ecological environment evaluation originated in the forest recreational value evaluation. M.Clawson (1959) using the consumer surplus presented travel cost method (TCM), which evaluated the forest recreation value according to travel expenses. Davis (1964) proposed the contingent valuation method (CVM), which was applied to the evaluation of Maine forest recreational value.

After the middle of the twentieth Century, the ecological environmental problem had gradually become the focus of attention. Krutilla(1967) published his article "Recognition of Natural Protection" in "American Economic Review", which marked the start of environmental and resource economics ( Ma Zhong, 1999).Thereafter, forest ecological environment evaluation, whose theoretical basis is environmental and resource economics, has become the research focus of the field of forest evaluation.

\section{Present situation of China's forest resources ecological environment}

Forest plays an extremely important role in the production and life of human being. With the constant development of social economy, China's forest was severely consumed and destroyed, for example, burning forest hunting, destroying forest and opening up wasteland, building materials, 
fuel demand and so on. In a word, with the expansion of population and development of social economy, China's forest appeared obvious trend of decline, no matter from quantity and quality.

On the other hand, China has implemented some measures to improve forest quality and quantity, which alleviated at a certain extent the trend of declination of forest quality.

\section{Uneven distributions of forest resources}

China's forest resources are uneven distributed. There is nearly half of the forest distributing in Heilongjiang, Jilin, northeast of Inner Mongolia, Sichuan, Yunnan and east of Tibet. The forest volume of these areas occupied approximately 3 / 4 of our country forest total volume.

In addition, the forest resources distribution presented "three zone" geographical regularity, that is, latitude, longitude and the vertical height. In the eastern humid area, from south to north, with heat increasing, there are the following different forest vegetation zones: the cold temperate coniferous forest zone, temperate coniferous and broad-leaved mixed forest zone, warm temperate deciduous broad-leaved forest zone, subtropical evergreen broad leaved forest zone, tropical seasonal rain forest and rain forest zone. The differentiation of forest vegetation zones reflects that China's forest distribution has horizontal zonal variation characteristics and is decided by the water and thermal situation of these geographical areas.

\section{Contradiction between wood utilization and forest sustainable development}

From age-class forest area and stock volume in national forest resources inventories (see Table 1), it is not difficult to see that the area and stock volume of young forest grow steadily in our country. So does half-mature forest. For young forest, the total growth range of area and stock volume upped to $24.71 \%$ and $162.33 \%$, and average annual growth range was $0.69 \%$ and $4.51 \%$ respectively since inventories. When it comes to half-mature forest the total growth range of area and stock volume also upped to $82.55 \%$ and $100.74 \%$, and average annual growth range was $2.29 \%$ and $2.8 \%$ respectively. While, for mature forest, the total growth range of area and stock volume merely was $22.52 \%$ and $26.62 \%$, and average annual growth range was $0.9 \%$ and $1.06 \%$ respectively in the late five inventories. Compared with young forest and half-mature forest, the growth range of mature forest was relatively small, which was related to the contradiction between wood utilization and forest sustainable development.

Table 1.Age-class forest area and stock volume in national forest resources inventories

\begin{tabular}{|c|c|c|c|c|c|c|c|c|c|}
\hline \multicolumn{3}{|c|}{ Age-class } & \multirow{2}{*}{$\begin{array}{c}1973 \sim \\
1976 \\
4217\end{array}$} & \multirow{2}{*}{$\begin{array}{c}1977 \\
\sim \\
1981 \\
3345\end{array}$} & \multirow{2}{*}{$\begin{array}{c}1984 \\
\sim \\
1988 \\
3958\end{array}$} & \multirow{2}{*}{$\begin{array}{c}1989 \sim \\
1993 \\
4133\end{array}$} & \multirow{2}{*}{$\begin{array}{c}1994 \\
\sim \\
1998 \\
4429\end{array}$} & \multirow{2}{*}{$\begin{array}{c}1999 \sim \\
2003 \\
4724\end{array}$} & \multirow{2}{*}{$\begin{array}{c}2004 \\
\sim \\
2009 \\
5259\end{array}$} \\
\hline $\begin{array}{l}\text { Young } \\
\text { forest }\end{array}$ & area & $\begin{array}{c}\text { Ten thousand } \\
\text { hectares }\end{array}$ & & & & & & & \\
\hline & $\begin{array}{c}\text { stock } \\
\text { volume }\end{array}$ & $\begin{array}{l}\text { Ten thousand } \\
\text { cubic meters }\end{array}$ & 56692 & 69962 & $\begin{array}{c}10282 \\
7\end{array}$ & 102318 & $\begin{array}{c}11540 \\
7\end{array}$ & $\begin{array}{c}12849 \\
7\end{array}$ & $\begin{array}{c}14872 \\
0\end{array}$ \\
\hline \multirow{2}{*}{$\begin{array}{l}\text { Half-ma } \\
\text { ture fore } \\
\text { st }\end{array}$} & area & $\begin{array}{l}\text { Ten thousand } \\
\text { hectares }\end{array}$ & 2851 & 3474 & 3259 & 3613 & 4289 & 4964 & 5204 \\
\hline & $\begin{array}{c}\text { stock } \\
\text { volume }\end{array}$ & $\begin{array}{l}\text { Ten thousand } \\
\text { cubic meters }\end{array}$ & 192374 & $\begin{array}{c}26866 \\
0 \\
\end{array}$ & $\begin{array}{c}23366 \\
3 \\
\end{array}$ & 266034 & $\begin{array}{c}30430 \\
3 \\
\end{array}$ & $\begin{array}{c}34257 \\
2 \\
\end{array}$ & $\begin{array}{c}38616 \\
4 \\
\end{array}$ \\
\hline \multirow{2}{*}{$\begin{array}{l}\text { Near-ma } \\
\text { ture fore } \\
\mathrm{st}^{1}\end{array}$} & area & $\begin{array}{c}\text { Ten thousand } \\
\text { hectares }\end{array}$ & - & - & 912 & 1106 & 1552 & 1999 & 2306 \\
\hline & $\begin{array}{c}\text { stock } \\
\text { volume }\end{array}$ & $\begin{array}{l}\text { Ten thousand } \\
\text { cubic meters }\end{array}$ & - & - & 98762 & 122142 & $\begin{array}{c}17334 \\
7\end{array}$ & $\begin{array}{c}22455 \\
1\end{array}$ & $\begin{array}{c}26497 \\
0\end{array}$ \\
\hline \multirow[t]{2}{*}{$\begin{array}{l}\text { Mature f } \\
\text { orest }\end{array}$} & area & $\begin{array}{l}\text { Ten thousand } \\
\text { hectares }\end{array}$ & 3213 & 2744 & 1528 & 1269 & 1492 & 1715 & 1872 \\
\hline & $\begin{array}{c}\text { stock } \\
\text { volume }\end{array}$ & $\begin{array}{l}\text { Ten thousand } \\
\text { cubic meters }\end{array}$ & 497454 & $\begin{array}{c}45921 \\
5\end{array}$ & $\begin{array}{c}24946 \\
3\end{array}$ & 220371 & $\begin{array}{c}26101 \\
6\end{array}$ & $\begin{array}{c}30166 \\
1\end{array}$ & $\begin{array}{c}31587 \\
9\end{array}$ \\
\hline \multirow{2}{*}{$\begin{array}{l}\text { Over-ma } \\
\text { ture fore } \\
\text { st }\end{array}$} & area & $\begin{array}{c}\text { Ten thousand } \\
\text { hectares }\end{array}$ & - & - & 562 & 742 & 810 & 877 & 918 \\
\hline & $\begin{array}{c}\text { stock } \\
\text { volume }\end{array}$ & $\begin{array}{l}\text { Ten thousand } \\
\text { cubic meters }\end{array}$ & - & - & $\begin{array}{c}12443 \\
4 \\
\end{array}$ & 197852 & $\begin{array}{c}20516 \\
7 \\
\end{array}$ & $\begin{array}{c}21248 \\
3 \\
\end{array}$ & $\begin{array}{c}22047 \\
4 \\
\end{array}$ \\
\hline
\end{tabular}

\footnotetext{
${ }^{1}$ Forest was divided into young forest, half-mature and mature forest in the first and second inventories; and has been joined near mature forest and over-matures forest since the third inventory.
} 
Data sources: National Forestry Bureau, 2005; National Forestry Bureau forest resources management department, 2000; National Forestry Bureau website, 2009; the People's Republic of China Ministry of Forestry Resource and Forestry Administration Department, 1996.

\section{Low quality of forest resources}

Compared with Asia and the world average level, our country forest quality was generally low. As shown in Table 2, world average per unit area volume was 110.7 cubic meters / hectare, Asian average per unit area volume was 82.4 cubic meters / hectare, but our country average per unit area volume was only 67.2 cubic meters / hectare. The carbon in per unit of biomass was71.5 tons / hectare, but in our country the carbon in per hectare was only 31 tons.

Table 2.Global forest quality in 2005

\begin{tabular}{|c|c|c|c|c|c|c|}
\hline \multirow[t]{3}{*}{ Area } & \multicolumn{2}{|c|}{ Stock volume } & \multicolumn{2}{|c|}{ Biomass } & \multicolumn{2}{|c|}{ Biomass carbon storage } \\
\hline & Per hectare & Total amount & Per hectare & Total amount & Per hectare & Total amount \\
\hline & $\begin{array}{c}\text { cubic meters } \\
\text { / hectare }\end{array}$ & $\begin{array}{c}\text { a hundred } \\
\text { million cubic } \\
\text { meters }\end{array}$ & Ton/ hectare & $\begin{array}{l}\text { a hundred } \\
\text { million ton }\end{array}$ & Ton/ hectare & $\begin{array}{l}\text { a hundred } \\
\text { million ton }\end{array}$ \\
\hline Africa & 101.7 & 638.57 & 191.3 & 1201.39 & 95.4 & 599.23 \\
\hline Asia & 82.4 & 469.43 & 114.9 & 653.96 & 57 & 324.56 \\
\hline Europe & 107.3 & 1062.76 & 87.7 & 875.09 & 43.7 & 436.14 \\
\hline $\begin{array}{c}\text { Central } \\
\text { America }\end{array}$ & 129.7 & 28.67 & 238.7 & 41.69 & 119.4 & 20.86 \\
\hline $\begin{array}{c}\text { South } \\
\text { America }\end{array}$ & 154.9 & 944.63 & 224 & 1514.64 & 110.1 & 744.64 \\
\hline $\begin{array}{c}\text { North } \\
\text { America }\end{array}$ & 111.1 & 681.01 & 125.1 & 379.29 & 62.6 & 189.64 \\
\hline Oceania & 35.7 & 10.77 & 113.5 & 186.60 & 51.2 & 84.14 \\
\hline world & 110.7 & 3840.04 & 144.7 & 4863.44 & 71.5 & 2404.39 \\
\hline China & 67.2 & 132.55 & 61.8 & 121.91 & 31 & 60.96 \\
\hline
\end{tabular}

Data sources: FAO, 2007; FAO, 2009

\section{Constructing evaluation and early warning index system}

This article will construct the evaluation and early warning index system of forest ecological environment from the following respects: natural environment, forest ecosystem and forest region social economy.

\section{Natural environments}

Natural environmental factors (see Table 3) include weather, atmosphere, water and soil. Meteorological factors such as rainfall, temperature, sunshine duration, the total amount of radiation can reflect forest growth potential. Atmosphere indexes can reflect the forest ecological environment quality and the pollution level. Water indexes can reflect the forest groundwater quality (such as $\mathrm{pH}$ value, conductivity, salinity), also can reflect the water pollution situation (such as BOD, COD); Forest soil is floristic growth medium. Soil cation exchange capacity can reflect the status of soil fertility of forest. Soil erosion modulus is an important index reflecting forest vegetation destruction degree. Soil $\mathrm{pH}$ value, soil heavy metal contents and pesticide residues can reflect forest soil salinization and pollution degree. 
Table3. Indicators of natural environments

\begin{tabular}{|c|c|c|}
\hline First-Level Indicators & $\begin{array}{c}\text { Second-Level } \\
\text { Indicators } \\
\end{array}$ & Third-Level Indicators \\
\hline \multirow{4}{*}{ Natural environments } & weather & $\begin{array}{l}\text { Rainfall, temperature, sunshine duration, the total amount } \\
\text { of radiation }\end{array}$ \\
\hline & atmosphere & $\mathrm{TSP}, \mathrm{SO}_{2}, \mathrm{NO}$ \\
\hline & water & $\begin{array}{l}\text { PH value, conductivity, Degree of mineralization, BOD, } \\
\text { COD }\end{array}$ \\
\hline & soil & $\begin{array}{l}\text { Cation exchange capacity, soil } \mathrm{pH} \text {, soil erosion modulus, } \\
\text { soil heavy metal contents, pesticide residues }\end{array}$ \\
\hline
\end{tabular}

\section{Forest ecological system}

Forest stand structure. According to the forest growth and development process, forest stand structure can be divided into five stages, namely, young forest, half-mature forest, near mature forest, mature forest and over-mature forest. Young forest is in a period before complete canopy, while half-mature forest appears between canopy closure and maturity. So, it is difficult for young forest and half-mature forest to play an important role in ecological environment. Near mature forest is about to enter the maturity and their diameter grows quickly. Mature forest entered the maturity, and their diameters grow slowly. Thus, near mature forest and mature forest have possessed a variety of ecological conditions, and become the best age group to bring into play ecological environment benefit. Over-mature forest stop growing and their useful value begin to gradually reduce. In a word, forest stand structure can largely reflect the quality of forest ecological environment, and is the representative index of forest ecological environment (see Table 4).

Insect pests. Forest insect pest is a major disaster for the growth of forest, because each process of forest growth is likely to be damaged by pest. Especially for man-made forest, single species greatly weaken the biological control mechanisms and some insects without predators' restriction largely populate resulting in population explosion, which become forests "pest"( Shen Xiaohui, 2004).So, forest insect pest showing the forest's quality is one of the important indexes of Forest Resources Ecological Environment.

Scenery and topography. Because the researchers' academic direction is different, previous studies may lead to different evaluation indexes (for example, plant pathology likes to choose pest as the health evaluation index, plant physiologist tend to use plant physiological indexes such as photosynthesis and water physiology, and ecologists like selecting biological diversity, biomass and other ecological index.), the index set is difficult to completely reflect the trend of forest health status or characteristics (Hu Chen xia,2005).In practice, scenery and topography has an important influence on forest quality, therefore this article select scenery and topography indexes to measure forest resources ecological environment. 
Table4. Indicators of forest ecological system

\begin{tabular}{|c|c|c|}
\hline $\begin{array}{c}\text { First-Level } \\
\text { Indicators }\end{array}$ & $\begin{array}{c}\text { Second-Level } \\
\text { Indicators }\end{array}$ & Third-Level Indicators \\
\hline \multirow{4}{*}{$\begin{array}{c}\text { Forest } \\
\text { ecological } \\
\text { system }\end{array}$} & Forest stand & $\begin{array}{c}\text { Tree species composition ; canopy density; } \\
\text { forest age } \\
\text { origin of forest stand }\end{array}$ \\
\cline { 2 - 3 } & Insect pest & $\begin{array}{c}\text { Pest index; Population density; Diversity index; } \\
\text { Dominance }\end{array}$ \\
\cline { 2 - 3 } & Topography & Richness; Natural degree; Diversity \\
& Shrub grass coverage ;gradient; Elevation \\
\hline
\end{tabular}

\section{Society and economy in forest region}

In 1976, Paul Samuelson put forward the concept of EKC2 and emphasized the importance of forest public policy arrangement at forest economics seminar. Grossman and Krueger(1991),studied the relationship between environmental quality and per capita income, and pointed out that the relationship between pollution and per capita income was that in low income level pollution would ascend when GDP per capita increasing ,but in low income level pollution would decline when GDP per capita increasing.

Social factors. This article selects population density, population growth rate, density of road network and proportion of non-agricultural population as the forest ecological environment evaluation and early warning index (see Table 5). High population growth rate and population density mean that the forest ecological environment capacity is reduced and will make the forest ecological environment threaten. Road network density can reflect the degree of forest zone traffic development, is a symbol of social modernization of forest.

Economic factors. The indexes, (for example gross output value of forest, forest economic growth rate, GDP per capita, Engel coefficient) can reflect the local forest economy status, thus reflect the forest growth and forest management status, indirectly reflect the quality of forest ecological environment, that is, sluggish forest zone economy benefit, on one hand may indirectly illustrate forest ecological environment in a healthy state, on the other hand means the forest ecological environment will be influenced by the danger of destruction.

Table 5.Indicators of society and economy in forest region

\begin{tabular}{|c|c|c|}
\hline First-Level Indicators & $\begin{array}{c}\text { Second-Level } \\
\text { Indicators }\end{array}$ & Third-Level Indicators \\
\hline \multirow{2}{*}{ Society and economy } & Social factors & $\begin{array}{c}\text { population density, population growth rate, density of road } \\
\text { network, proportion of non-agricultural population }\end{array}$ \\
\cline { 2 - 3 } & $\begin{array}{c}\text { Economic } \\
\text { factors }\end{array}$ & $\begin{array}{r}\text { gross output value of forest, forest economic growth rate, } \\
\text { GDP per capita, Engel coefficient }\end{array}$ \\
& & a
\end{tabular}

\footnotetext{
${ }^{2}$ In 1993 Panayotou referred to the relationship between environmental quality and per capita income as Environment Kuznets Curve (EKC)
} 


\section{Conclusion}

At present, the forest ecological environment evaluation and early warning indexes have no uniform and accepted standards. This article preliminary discuss the evaluation and early warning index system of forest ecological environment from the following respects: natural environment, forest ecosystem and forest region social economy. These indexes need to bind with practice in order to better apply to practice.

\section{Reference}

[1] FAO, State of the World's Forests 2007, Rome, Italy, viii-ix, 2007

[2] Jenkins A F, Forest Health: A Crisis of Human Proportions [J].Journal of Forestry, 1997, 95(9):11-14.

[3] Krutilla, J. Conservation reconsidered [J]. American Economic Review, 1967.

[4] M.clawson, "The Crisis in Outdoor Recreation", American Forests, Vol.65, nos.3 and 4 (March and April, 1959)

[5] Grossman, G. M., Kruger, A. B., "Environmental Impacts of a North American Free Trade Agreement", National Bureau of Economic Research Working Paper, 3914,NBER,Cambridge MA, 1991

[6] Panayotou, Theodore, "Empirical Tests Environmental Degradation at Different Stages of Economic Programme Research Working Paper, Geneva and Policy Analysis of Development", World: International Labour Office,1993. 